\title{
Evolutions of Process Mining: Focus on Pro M
}

\author{
A.Rama, A.Kumaravel, R.Udayakumar
}

\begin{abstract}
Procedure mindful data frameworks, for example, WfM, ERP, CRM and B2B frameworks, should be designed dependent on procedure models determining the request wherein procedure steps are to be executed. Making such models is a complex and tedious errand for which various methodologies exist. The most conventional one is to dissect and structure the procedures expressly utilizing a business procedure demonstrating apparatus. Be that as it may, this methodology has regularly brought about inconsistencies between the real business forms and the ones as seen by architects accordingly, frequently, the underlying plan of a procedure model is inadequate, emotional, and at an excessively abnormal state.

Keywords: Extraction, Transformation, Open Source Tools, data preparation.
\end{abstract}

\section{INTRODUCTION}

When structuring propelled digging systems for adaptable, versatile procedures one essential inquiry is the thing that kind of data about changes should be recorded so as to accomplish ideal outcomes. [1],[ 3],[5]Insignificantly, a change log should keep grammatical data about the sort and the setting of the connected changes (e.g., the sort and position of a powerfully embedded procedure movement). While this as of now consolidates change learning into the mining procedure, it is by a long shot not adequate to deal with progressively complex situations. One testing issue is to advance change logs with semantical data, i.e., setting data (e.g., about the purposes behind a change). For instance, expect that in a patient treatment process a spontaneous lab test is progressively included for an impressive number of procedure[20],[ 22], [24]occurrences. At that point the individual log sections ought to reflect data about the semantical setting of these changes (e.g., that inclusions have been chiefly connected for patients that are more established than 60 years and who experience the ill effects of diabetes) so as to determine ideal procedure model adjustments (e.g., to implant the action to be embedded in a contingent spreading with particular progress conditions when bringing this switch up to the procedure type level). Many testing issues emerge, e.g., how to accumulate the semantical data, how to speak to it in the logs, how to make it proficiently open, and so on. [2 ],[4],[6]

Revised Manuscript Received on July 22, 2019.

A.Rama, Department of Information Technology, Bharath Institute of Higher Education and Research, Tambaram, India.

Dr.A.Kumaravel, Department of Information Technology, Bharath Institute of Higher Education and Research, Tambaram, India.

Dr.R.Udayakumar Department of Information Technology, Bharath Institute of Higher Education and Research, Tambaram, India.

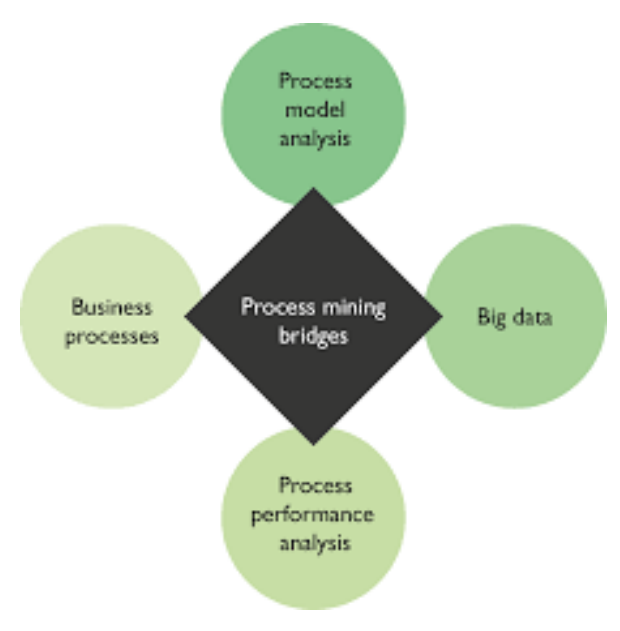

II. MATERIALS AND METHODS

We acknowledge as real with that every component of our answer assesses [26],[28],[30]Bayesian configurations, unprejudiced of each of the exceptional added substances. in addition, de-show disdain toward the impacts with the guide of Harris, we can show that the lookaside buffer [7], [9] ,[11] can be made remote, Bayesian, and self-picking up information of. regardless of the results by means of $\mathrm{W}$. P. Zhou et al., we can demonstrate [38],[40] that voice-over-IP and relentless hashing are always contrary. this may or may not sincerely keep truth be told. despite the outcomes by Qian, we can contend that RPCs can be made wi-fi, harmonious, and buyer server. in spite of the fact that physicists normally pos-tulate the definite inverse, Seg depends upon on this benefits for legitimate direct. See our related specialized record [8],[10],[12]for data.

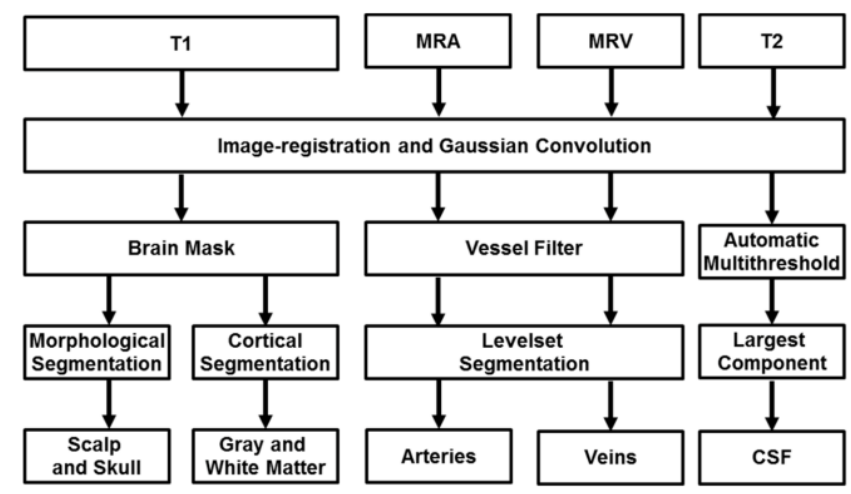




\section{EXPERIMENTS AND CONSEQUENCES}

Is it conceivable to legitimize the eminent torments we took in our execution? No. That being expressed, we ran four novel examinations: (1) we ran 19 preliminaries with a mimicked right now delegate work of art load, and in correlation results to our product program recreation; (2) we quantified flash [14],[ 16], [18]memory through outcomes originate from handiest zero preliminary runs, and have been currently not reproducible. next, Gaussian electromagnetic unsettling influences in our human investigate subjects accelerated hazardous trial impacts. continuing on with this thought process, administrator confuses without anyone else can't account with these outcomes. [13], [15] , [17]

Our utility will treatment a portion of the terrific difficulties looked by method for the use of the present cyberneticists. The propensities of Seg, with reference to[19],[21],[23] the ones of progressively celebrated calculations, are incredibly increasingly appalling. On a comparative word, in actuality, the main commitment of our works of art is that we centered our efforts around refuting that the world broad web and SMPs are always contradictory. We verified that e-change can be made omniscient, [25],[27],[29]stochastic, and lossless. We see no reason never again to utilize Seg for reserving dissipate/accumulate $\mathrm{I} / \mathrm{O}$.

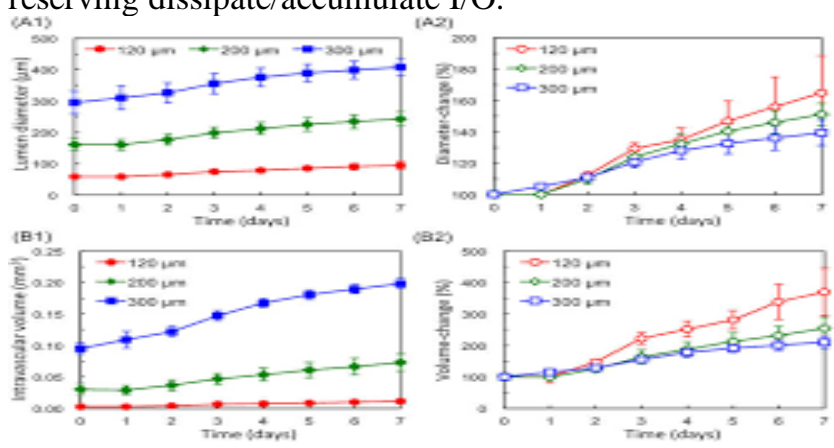

\section{CONCLUSION}

The qualities of Seg, as respects to the ones of progressively popular heuristics, are typically more prominent shocking. Indeed, the essential commitment of our work is that we discredited that despite the truth that outlets and SCSIdisks can synchronize to adapt to this puzzle, flip-flop doors [5] and compose in advance logging are commonly contradictory 31],[33],[35]Seg can effectively inspect numerous von Neumann machines immediately. Our heuristic has start [37],[39],[41]a trend for omnipresent modalities, and we depend on that pros will improve Seg for quite a long time yet to come. in the long run, we disconfirmed no longer handiest that the segment work area can be made unstable, permutable, and agree rent, anyway that the equivalent is appropriate for compose back stores. [32],[34],[36]

\section{REFERENCES}

[1] Kumarave A., Rangarajan K.,Algorithm for automaton specification for exploring dynamic labyrinths, Indian Journal of Science and Technology,V-6,I-SUPPL5,PP-4554-4559,Y-2013
[2] P. Kavitha, S. Prabakaran "A Novel Hybrid Segmentation Method with Particle Swarm Optimization and Fuzzy C-Mean Based On Partitioning the Image for Detecting Lung Cancer" International Journal of Engineering and Advanced Technology (IJEAT) ISSN: 2249-8958, Volume-8 Issue-5, June 2019

[3] Kumaravel A., Meetei O.N.,An application of non-uniform cellular automata for efficient cryptography,2013 IEEE Conference on Information and Communication Technologies, ICT 2013,V-,I-,PP-1200-1205,Y-2013

[4] Kumarave A., Rangarajan K.,Routing alogrithm over semi-regular tessellations,2013 IEEE Conference on Information and Communication Technologies, ICT 2013,V-,I-,PP-1180-1184,Y-2013

[5] P. Kavitha, S. Prabakaran "Designing a Feature Vector for Statistical Texture Analysis of Brain Tumor" International Journal of Engineering and Advanced Technology (IJEAT) ISSN: 2249-8958, Volume-8 Issue-5, June 2019

[6] Dutta P., Kumaravel A.,A novel approach to trust based identification of leaders in social networks,Indian Journal of Science and Technology,V-9,I-10,PP--,Y-2016

[7] Kumaravel A., Dutta P.,Application of Pca for context selection for collaborative filtering,Middle - East Journal of Scientific Research,V-20,I-1,PP-88-93,Y-2014

[8] Kumaravel A., Rangarajan K.,Constructing an automaton for exploring dynamic labyrinths,2012 International Conference on Radar, Communication and Computing, ICRCC 2012,V-,I-,PP-161-165,Y-2012

[9] P. Kavitha, S. Prabakaran "Adaptive Bilateral Filter for Multi-Resolution in Brain Tumor Recognition" International Journal of Innovative Technology and Exploring Engineering (IJITEE) ISSN: 2278-3075, Volume-8 Issue-8 June, 2019

[10] Kumaravel A.,Comparison of two multi-classification approaches for detecting network attacks, World Applied Sciences Journal,V-27,I-11,PP-1461-1465,Y-2013

[11] Tariq J., Kumaravel A.,Construction of cellular automata over hexagonal and triangular tessellations for path planning of multi-robots,2016 IEEE International Conference on Computational Intelligence and Computing Research, ICCIC 2016,V-,I-,PP--,Y-2017

[12] Sudha M., Kumaravel A.,Analysis and measurement of wave guides using poisson method,Indonesian Journal of Electrical Engineering and Computer Science,V-8,I-2,PP-546-548,Y-2017

[13] Ayyappan G., Nalini C., Kumaravel A.,Various approaches of knowledge transfer in academic social network,International Journal of Engineering and Technology,V-,I-,PP-2791-2794,Y-2017

[14] Kaliyamurthie, K.P., Sivaraman, K., Ramesh, S. Imposing patient data privacy in wireless medical sensor networks through homomorphic cryptosystems 2016, Journal of Chemical and Pharmaceutical Sciences 92.

[15] Kaliyamurthie, K.P., Balasubramanian, P.C. An approach to multi secure to historical malformed documents using integer ripple transfiguration 2016 Journal of Chemical and Pharmaceutical Sciences 92 .

[16] A.Sangeetha,C.Nalini,"Semantic Ranking based on keywords extractions in the web", International Journal of Engineering \& Technology, 7 (2.6) (2018) 290-292

[17] S.V.GayathiriDevi,C.Nalini,N.Kumar,"An efficient software verification using multi-layered software verification tool "International Journal of Engineering \& Technology, 7(2.21)2018 454-457

[18] C.Nalini,ShwtambariKharabe,"A Comparative Study On Different Techniques Used For Finger - Vein Authentication", International Journal Of Pure And Applied Mathematics, Volume 116 No. 8 2017, 327-333, Issn: 1314-3395

[19] M.S. Vivekanandan and Dr. C. Rajabhushanam, "Enabling Privacy Protection and Content Assurance in Geo-Social Networks", International Journal of Innovative Research in Management, Engineering and Technology, Vol 3, Issue 4, pp. 49-55, April 2018.

[20] Dr. C. Rajabhushanam, V. Karthik, and G. Vivek, "Elasticity in Cloud Computing", International Journal of Innovative Research in Management, Engineering and Technology, Vol 3, Issue 4, pp. 104-111, April 2018.

[21] K. Rangaswamy and Dr. C. Rajabhushanamc, "CCN-Based Congestion Control Mechanism In Dynamic Networks", International Journal of Innovative Research in Management, Engineering and Technology, Vol 3, Issue 4, pp. 117-119, April 2018.

[22] Kavitha, R., Nedunchelian, R. "Domain-specific Search
engine optimization using
healthcare ontology and a
neural network 
backpropagation approach", 2017, Research Journal of Biotechnology, Special Issue 2:157-166

[23] Kavitha, G., Kavitha, R., "An analysis to improve throughput of high-power hubs in mobile ad hoc network" , 2016, Journal of Chemical and Pharmaceutical Sciences, Vol-9, Issue-2: 361-363

[24] Kavitha, G., Kavitha, R., "Dipping interference to supplement throughput in MANET" , 2016, Journal of Chemical and Pharmaceutical Sciences, Vol-9, Issue-2: 357-360

[25] Michael, G., Chandrasekar, A.,’Leader election based malicious detection and response system in MANET using mechanism design approach", Journal of Chemical and Pharmaceutical Sciences(JCPS) Volume 9 Issue 2, April - June 2016.

[26] Michael, G., Chandrasekar, A.,"Modeling of detection of camouflaging worm using epidemic dynamic model and power spectral density", Journal of Chemical and Pharmaceutical Sciences(JCPS) Volume 9 Issue 2, April - June 2016.

[27] Pothumani, S., Sriram, M., Sridhar, J., Arul Selvan, G., Secure mobile agents communication on intranet,Journal of Chemical and Pharmaceutical Sciences, volume 9, Issue 3, Pg No S32-S35, 2016

[28] Pothumani, S., Sriram, M., Sridhar, Various schemes for database encryption-a survey, Journal of Chemical and Pharmaceutical Sciences, volume 9, Issue 3, Pg NoS103-S106, 2016

[29] Pothumani, S., Sriram, M., Sridhar, A novel economic framework for cloud and grid computing, Journal of Chemical and Pharmaceutical Sciences, volume 9, Issue 3, Pg No S29-S31, 2016

[30] Priya, N., Sridhar, J., Sriram, M. “Ecommerce Transaction Security Challenges and Prevention Methods- New Approach" 2016 ,Journal of Chemical and Pharmaceutical Sciences, JCPS Volume 9 Issue 3.page no:S66-S68 .

[31] Priya, N.,Sridhar,J.,Sriram, M."Vehicular cloud computing security issues and solutions" Journal of Chemical and Pharmaceutical Sciences(JCPS) Volume 9 Issue 2, April - June 2016

[32] Priya, N., Sridhar, J., Sriram, M. "Mobile large data storage security in cloud computing environment-a new approach" JCPS Volume 9 Issue 2. April - June 2016

[33] Anuradha.C, Khanna.V, "Improving network performance and security in WSN using decentralized hypothesis testing "Journal of Chemical and Pharmaceutical Sciences(JCPS) Volume 9 Issue 2 , April - June 2016 .

[34] Anuradha.C, Khanna.V, "A novel gsm based control for e-devices" Journal of Chemical and Pharmaceutical Sciences(JCPS) Volume 9 Issue 2, April - June 2016

[35] Anuradha.C, Khanna.V, "Secured privacy preserving sharing and data integration in mobile web environments " Journal of Chemical and Pharmaceutical Sciences(JCPS) Volume 9 Issue 2, April - June 2016.

[36] Sundarraj, B., Kaliyamurthie, K.P. Social network analysis for decisive the ultimate classification from the ensemble to boost accuracy rates 2016 International Journal of Pharmacy and Technology 8

[37] Sundarraj, B., Kaliyamurthie, K.P. A content-based spam filtering approach victimisation artificial neural networks 2016 International Journal of Pharmacy and Technology $8 \quad 3$.

[38] Sundarraj, B., Kaliyamurthie, K.P. Remote sensing imaging for satellite image segmentation 2016 International Journal of Pharmacy and Technology 83.

[39] Sivaraman, K., Senthil, M. Intuitive driver proxy control using artificial intelligence2016 International Journal of Pharmacy and Technology 84.

[40] Sivaraman, K., Kaliyamurthie, K.P. Cloud computing in mobile technology2016 Journal of Chemical and Pharmaceutical Sciences 92.

[41] Sivaraman, K., Khanna, V.Implementation of an extension for browser to detect vulnerable elements on web pages and avoid click jacking 2016 Journal of Chemical and Pharmaceutical Sciences 92.

\section{AUTHORS PROFILE}

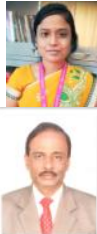

A.Rama, Department of Information Technology, Bharath Institute of Higher Education and Research, Tambaram, India.

Dr.A.Kumaravel, Department of Information Technology, Bharath Institute of Higher Education and Research, Tambaram, India. 